\title{
Sonneratia ovata Backer (Lythraceae): status and distribution of a Near Threatened mangrove species in tsunami impacted mangrove habitats of Nicobar Islands, India
}

\author{
P. Nehru ${ }^{1} \&$ P. Balasubramanian ${ }^{2}$ \\ 1,2 Division of Landscape Ecology, Salim Ali Centre for Ornithology and Natural History, Anaikatty (P.O.), Coimbatore, Tamil Nadu \\ 641108, India \\ Email: ${ }^{1}$ nehrumcc@gmail.com (corresponding author), ${ }^{2}$ balusacon@yahoo.com
}

Mangrove forests are the most productive ecosystem adapted to thrive in the coastal margins of the tropics (Ellison \& Fransworth 2001). The ecosystem service provided by mangroves includes breeding grounds for many marine organisms, a carbon sink and is also the main source of economy for coastal dwelling human communities (Kathiresan \& Bingham 2001). Mangrove ecosystems play a major role in protecting coastal regions from natural calamities such as storms, hurricanes and tsunamis. Regardless of the services provided, mangrove forests are disappearing from the world at an alarming rate of $1 \%$ per year and almost $35 \%$ of the mangroves have disappeared in the last two decades of the $20^{\text {th }}$ century (Valiela et al. 2001).

Date of publication (online): 26 December 2012

Date of publication (print): 26 December 2012

ISSN 0974-7907 (online) | 0974-7893 (print)

Editor: Marília Cunha Lignon

Manuscript details:

Ms \# 03009

Received 16 November 2011

Final received 20 August 2012

Finally accepted 25 October 2012

Citation: Nehru, P. \& P. Balasubramanian (2012). Sonneratia ovata Backer (Lythraceae): status and distribution of a Near Threatened mangrove species in tsunami impacted mangrove habitats of Nicobar Islands, India. Journal of Threatened Taxa 4(15): 3395-3400.

Copyright: (C) P. Nehru \& P. Balasubramanian 2012. Creative Commons Attribution 3.0 Unported License. JoTT allows unrestricted use of this article in any medium for non-profit purposes, reproduction and distribution by providing adequate credit to the authors and the source of publication.

Acknowledgements: The financial support received from the Forest Department of Andaman and Nicobar Islands is gratefully acknowledged. We thank Shri. Negi PCCF (WL), Shri. Ajai Saxena, CCF and Dinesh Kannan DFO of Forest Department of Andaman and Nicobar Islands for their interest in the project. Comments by Dr. Aris Dason, Assistant professor, Madras Christian College and Dr. H. N. Kumara, Scientist, SACON helped us to improve the manuscript. Mr. P. Rajan, SACON helped us in map preparation.

\section{OPEN ACCESS | FREE DOWNLOAD}

Abstract: The world's most productive ecosystem, the mangrove forest, is under immense pressure due to natural and human induced disturbances. The Indian Ocean tsunami on 26 December 2004 had an adverse effect on these habitats by breaking and uprooting the mangrove trees. The mangrove vegetation and the coastal forest of Nicobar Islands, India, were severally damaged by the force of the tsunami and the loss of habitat due to the sudden rise in sea level. We studied the recolonization of mangroves species that began after the tsunam over 19 Islands and 25 locations present in the Nicobar group. Sonneratia ovata (Lythraceae), a Near Threatened landward mangrove species, is reported for the first time from India. A total of 43 individuals of $S$. ovata was recorded from two sites, namely, Oh Hi Poh and Dhili Kadi, on Katchall Island. All the individuals of mangrove species $\geq 1 \mathrm{~cm}$ girth at breast height were counted from both sites. The relative density for Bruguiera gymnorhiza $(77 \%)$ and Sonneratia caseolaris $(77 \%)$ are high at Oh $\mathrm{Hi}$ Poh and Dhili Kadi, respectively. Global distribution, occurrence in India, threats and conservation of $S$. ovata are discussed in detail. The influence of the tsunami in the dispersal of $S$. ovata from the nearest known sources Thailand, Malaysia or Indonesia is not very clear. Hence, molecular based study is required for the confirmation of the possible seed source location.

Keywords: Habitat destruction, Indian Ocean tsunami, mangrove, recolonization, Sonneratia ovata.

The remaining mangrove forests are under immense anthropogenic pressure from felling, encroachment, shrimp cultivation, hydrological alterations, chemical spills, and land conversion (McKee 2005; Giri et al. 2008). Natural disturbances such as storms, hurricanes, tsunamis, land elevation or submergence due to tectonic movements, climate change and sea level rise are also threatening this biologically important ecosystem.

The mega earthquake of 9.15 magnitude and the following tsunami on 26 December 2004 had a serious impact on the human population and on the biodiversity of the coastal regions in the Asian countries such as India, Sri Lanka, Indonesia, Burma, Thailand, Singapore and Malaysia. The close vicinity of the Nicobar Islands to the epicenter of the earthquake resulted in a heavy impact on the mangroves and 
littoral forests. It was variously estimated that the tsunami wiped off $60-70 \%$ of the mangrove forests in the Nicobar Islands (Ramachandran et al. 2005; Sridhar et al. 2006). More importantly, subduction of the Indian plate with the Burma plate during this mega earthquake caused the Nicobar Islands to sink into the sea by about $1 \mathrm{~m}$, this resulted in a rise in the sea level in the coastal areas where mangroves and littoral evergreen vegetation were prevalent (Sankaran 2005; Sivakumar 2007). Perennial submergence of pneumatophores resulted in the scorching of mangrove trees due to the hypoxic condition. This submergence also resulted in the formation of new inter tidal areas at the expense of flat coastal forests (littoral forest) and coconut plantations that existed adjacent to the coast (Nehru \& Balasubramanian 2011) and mangroves started colonizing in these newly formed habitats (NFH).

The post tsunami research work in the Nicobar Islands on mangroves are almost all based only on remote sensing and GIS (Ramachandran et al. 2005; Sridhar et al. 2006; Porwal et al. 2012). A single field based study that described the mangrove plant species diversity in the NFH of Central Nicobar Group of Islands was by Nehru \& Balasubramanian (2011).

The current study describes the population, distribution and microhabitat preference of the Near Threatened mangrove species Sonneratia ovata Backer (Lythraceae) from the NFH after the tsunami impact.

\section{Materials and Methods}

We surveyed the Nicobar Islands from October 2010 to July 2011 for assessing the colonization of mangrove species in the NFH. Excluding Batti Malv, Isle of Man and Megapode Island, the entire coastal line of all the other 19 islands, viz., Car Nicobar, Chowra, Bombuka, Teresa, Tillanchong, Kamorta, Trinket, Nancowrie, Katchall, Great Nicobar, Little Nicobar, Kondul, Kobra, Manchal, Pigeon, Pilomilo, Tris, Trak, and Meroe of the Nicobar group were surveyed (Fig. 1).

It is to be noted that the Megapode Island which was largely covered by mangrove vegetation prior to the tsunami was totally submerged into the sea after the tsunami (Sankaran 2005). Apart from a single scorched tree stump in the middle of the sea, no evidence was found during the present study confirming the existence of this island.
Qualitative data on inundation levels, substratum, freshwater influx, pre tsunami history of the habitat, adjacent forest type, tsunami destruction level, number of colonizing mangroves and mangrove associates were noted for each NFH by direct observation. Geographic coordinates were taken using the Garmin $76 \mathrm{C} \mathrm{SX}$ at all the localities and the area was calculated using the GE-path software package (ver. 1.4.6).

All the individuals $\geq 1 \mathrm{~cm}$ girth at breast height (GBH) of mangroves species present in the NFH were enumerated. The whole population of $S$. ovata was enumerated and each individual was tagged. Samples of all the mangrove species were collected for herbarium purpose. Relative density was calculated for mangrove species studied in Katchall Island.

\section{Results}

In total, 25 localities distributed over eight islands were observed to have NFH. S. ovata was observed only on Katchall Island $\left(7^{0} 51^{\prime}-8^{\circ} 01^{\prime} \mathrm{N} \& 9^{\circ} 17^{\prime}-\right.$ $93^{\circ} 28^{\prime} \mathrm{E}$ ) at two localities namely $\mathrm{Oh} \mathrm{Hi}$ Poh and Dhili Kadi where vast stretch of littoral forest existed prior to tsunami, but are presently colonized by mangroves (Fig. 1). The total area of NFH at these two locations was 23.9 and 4.64 ha, respectively. The littoral forest existing in these two locations experienced different modes of destruction during the tsunami leading to the transformation into mangrove forests. At $\mathrm{Oh} \mathrm{Hi}$ Poh, the littoral forest that existed prior to the tsunami was uprooted and resulted in the deposition of copious amount of logs in the substratum (Image 1a). At Dhili Kadi, the entire stretch of littoral vegetation was scorched due to salt stress and hypoxia created by the rise of sea level leaving a vast stretch of snags (Image 1b). A total of 43 live individuals of $S$. ovata were recorded (13 at Oh Hi Poh and 30 at Dhili Kadi) along the edges of the NFH abutting the evergreen hill forest. The relative density was high for Bruguiera gymnorhiza (77\%) and Sonneratia caseolaris $(77 \%)$ at the NFH studied at Dhili Kadi ( $\mathrm{n}=114)$ and Oh Hi Poh $(\mathrm{n}=237)$, respectively (Figs. 2\&b).

$S$. ovata was always found intermixed with the associated species (viz. B. gymnorhiza, S. caseolaris, Barringtonia racemosa and Crataeva religiosa), whereas its conspecific $S$. caseolaris was mostly found as mono-dominat patches with out any associated species. The substratum in both these sites was muddy clay towards the sea and firm clay inland. S. ovata is 


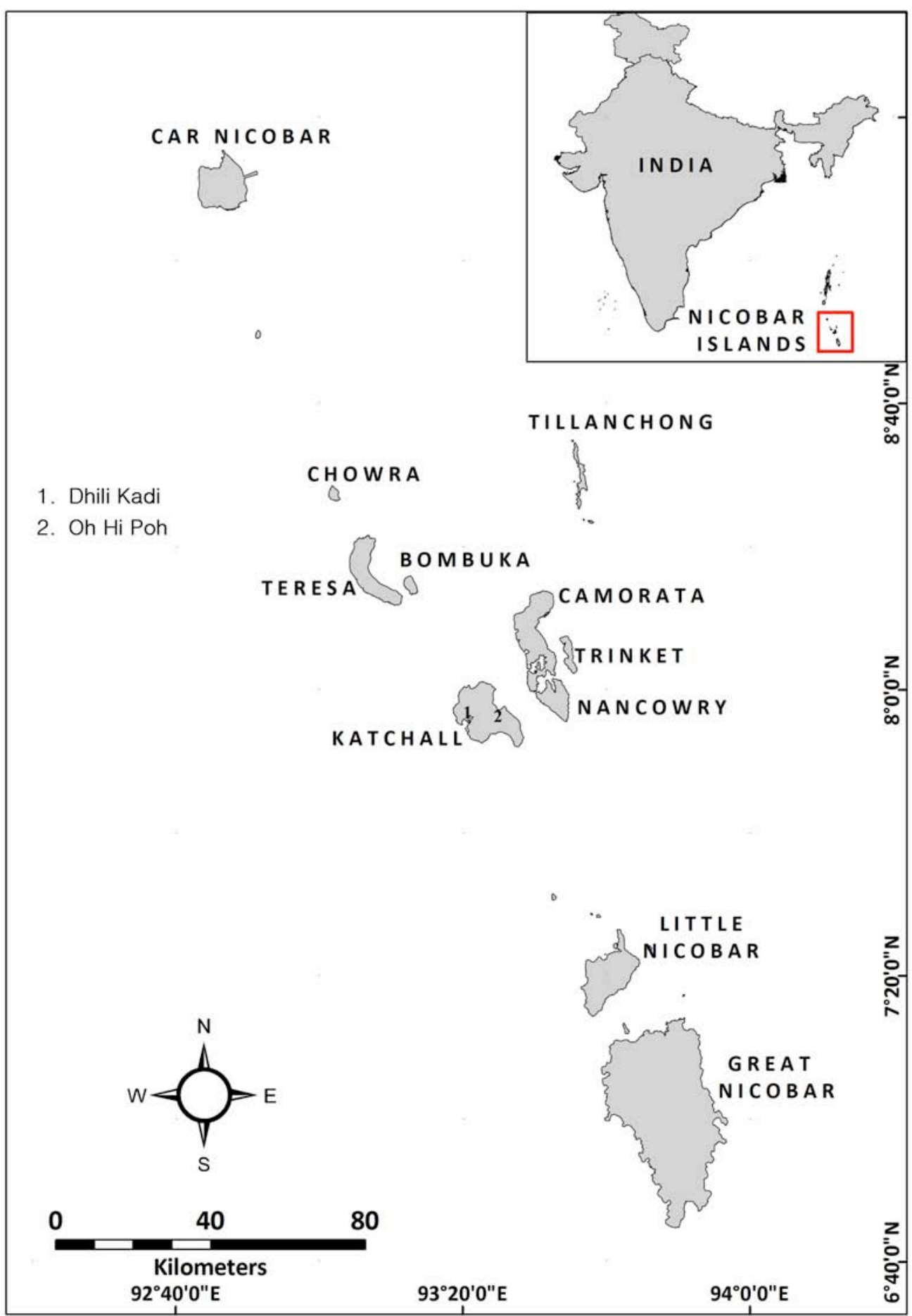

Figure 1. Nicobar Islands, India, showing the study localities, on Katchall Island, where Sonneratia ovata was observed: 1 Dhili Kadi; 2 - Oh Hi Poh.

found in the firm clay substratum towards the landward mangrove forest edge where constant seepage of freshwater from the hill forest was observed.

S. ovata is distinguished from other species of the genus Sonneratia by (i) having verrucose texture on the outer surface of the calyx, (ii) fruits are enclosed by persistent calyx, and the calyx are either reflexed or flat in the other species (iii) and suborbicular coriaceous leaves without a mucronate apex. S. ovata normally grows in the landward mangrove habitats where sea water enters only during full moon and spring tides. A detailed description and the nomenclature of the 

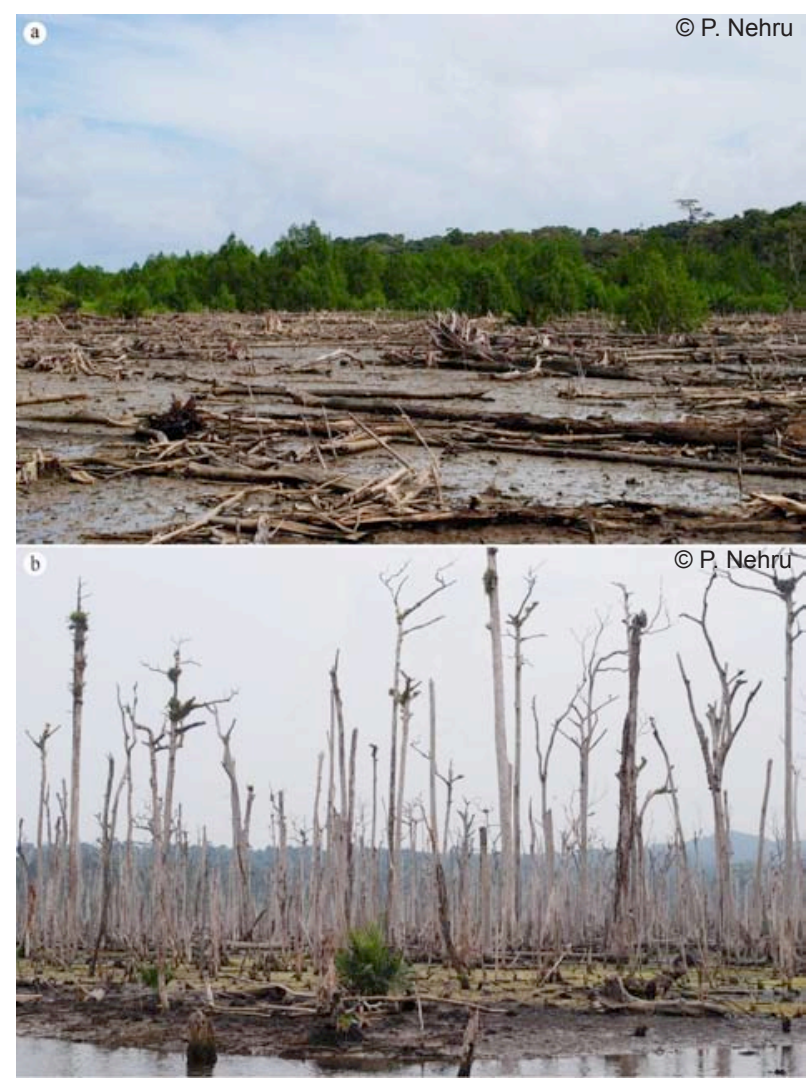

Image 1. a - A view of Oh Hi Poh NFH showing deposition of logs in the substratum by uprooted trees (23.xi.2010); b - A view of Dhili Kadi NFH showing vast stretch of snags (28.iv.2011)

species are given below.

Sonneratia ovata Backer, Bull. Jard. Bot. Buitenzorg Ser. 3, 2: 329. 1920; Qin \& al. in Wu \&
Raven, Fl. China 13: 287. 2007.

Trees up to $8 \mathrm{~m}$ high; bark lenticellate; pneumatophores ca. $20 \mathrm{~cm}$ high, thin, pointed. Leaves opposite, sub-orbicular to ovate-elliptic, 5.5-9 × 4-8 $\mathrm{cm}$, attenuate to cuneate at base, entire to undulate at margins, obtuse at apex, coriaceous; petioles $0.8-1.5$ cm long. Flowers 1-3, terminal, ca. $3 \mathrm{~cm}$ across, white. Bracts orbicular, ca. $0.5 \mathrm{~cm}$, cauducous. Pedicels 1.5$2 \mathrm{~cm}$ long. Sepals 6, coriaceous, verrucose outside, smooth, pinkish at base inside. Petals 6, linear, 1.5-2 x $0.1-0.2 \mathrm{~cm}$, white. Stamens numerous; filaments 2-3 cm long; anthers basifixed. Style 1.8-2.5 cm long; stigma capitate. Berry sub-globose, $2.5-3 \times 3-4 \mathrm{~cm}$, ca. $1 / 3$ of the fruit enclosed within persistent calyx; seeds numerous.

Flowering and fruiting: Throughout the year with peaks during February-March and July-August (Images $2 \mathrm{a} \& \mathrm{~b}$ ).

Specimen examined: 28.vi.2011, Andaman and Nicobar Islands, Nicobar District, Katchall Island, Dhili Kadi, P. Nehru (189). The voucher specimen is deposited in SACON Herbarium.

\section{Discussion and Conclusions}

The genus Sonneratia has six species distributed in the tropical mangrove forests from East Africa to Australia (Mabberley 2005). In India, it is represented by four species namely S. alba, S. apetala, S. caseolaris and $S$. grifithii (Banerjee et al. 2002). Occurrence of $S$. ovata within the Indian territory has not been reported
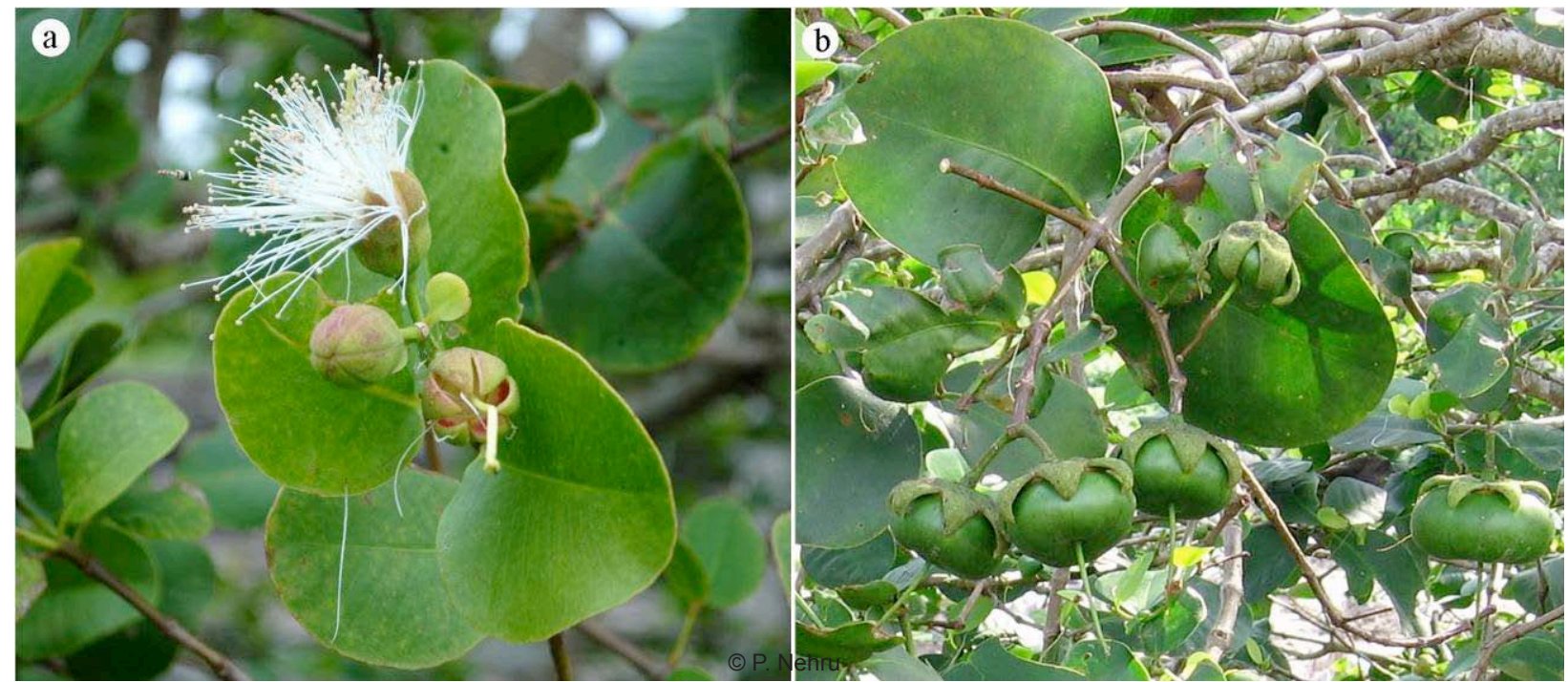

Image 2. a - Inflorescence of Sonneratia ovata (23.xi.2010); b - Fruiting twig of S.ovata (28.iv.2011) 

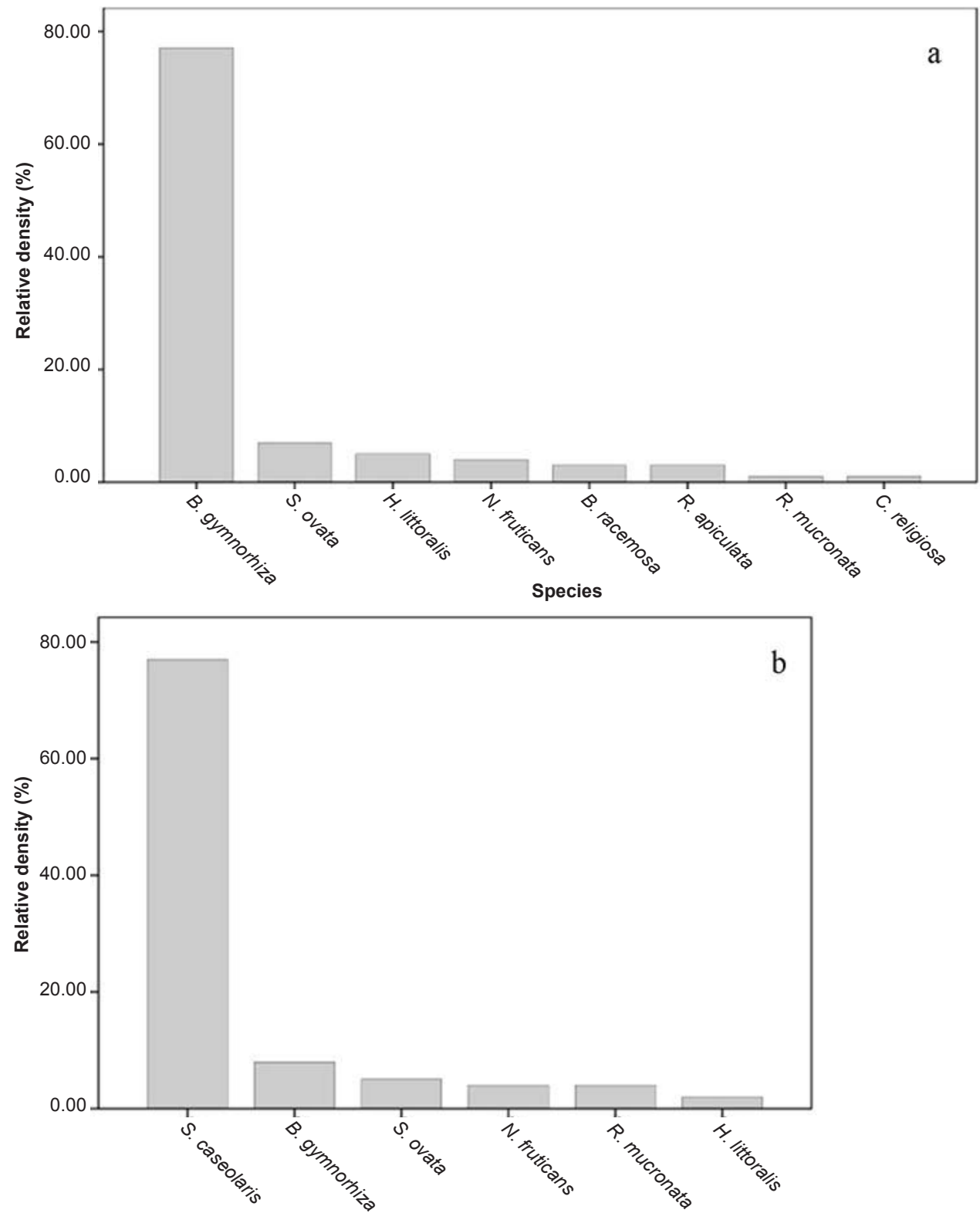

Figure 2. Relative density of mangrove species at Dhili Kadi (a) and Oh Hi Poh (b) on Katchall Island

(Banerjee et al. 1989; Dagar et al. 1991; Banerjee et al. 2002; Mandal \& Naskar 2008; Yi-feng et al. 2011). Thus the present report is a new record for the flora of India. This species is distributed in East and Southeast Asian countries such as China, Malaysia, Singapore, Thailand, Indonesia, New Guinea and Vietnam (Haining et al. 2007) and categorized as Near-Threatened by IUCN due to severe habitat loss throughout its distributional range (Polidoro et al. 2010).

There are two probable reasons for the occurrence of S.ovata on Nicobar Islands. Dagar et al. (1991) has noticed an individual of Sonneratia spp. at Katchall
Island without any reproductive parts and speculated its identity as $S$. grifithii. If it was a misidentification of S. ovata, then possibly this species must have existed very rarely prior to the tsunami, and later became common in the NFH of Katchall Island. Or, the seeds of $S$. ovata from the nearest sources viz. Indonesia, Malaysia and Singapore must have been carried by the tsunami and established a new population on Katchall Island.

Sonneratia spp. along with Avicennia are usually considered pioneers of mangrove swamps and seeds of Sonneratia spp. are intolerant to shade, germinating on bare or near bare mud banks (Duke \& Jakes 
1987). Hence, the scorching of littoral forests due to salt stress has resulted in the formation of open area and the heliophilic nature of $S$. ovata has eventually ameliorated the species to colonize the NFH. The occurrence of $S$. ovata in the NFH abutting the evergreen hill forests confirms the landward movement of mangroves when subjected to sea level rise, as proposed by Ellison (2005). Landward mangroves are vulnerable to sea-level rise, since there may not be any habitat to re-establish because mangrove edges are highly influenced by human developmental activities (Polidoro et al. 2010).

It is strongly recommended to include landward mangrove species such as Sonneratia spp. in the mangrove restoration programs as many of the current programs give emphasis mainly to seaward mangroves such as Rhizophora spp., and Avicennia spp. (Ellison 2000). Further research based on molecular tools can provide more information on the occurrence of S.ovata on Katchall Island.

\section{REFERENCES}

Banerjee, L.K., A.R.K. Sastry \& M.P. Nayar (1989). Mangroves in India identification manual. Botanical Survey of India, Culcutta,110pp.

Banerjee, L.K., T.A. Rao, A.R.K. Sastry \& D. Ghosh (2002). Diversity of Coastal Plant Communities in India. ENVIS \& EMCBTAP, Botanical Survey of India, Kolkata, 524pp.

Dagar, J.C., A.D. Mongia \& K. Bandopadhyay (1991). Mangroves of Andaman \& Nicobar Islands. IBH \& Oxford Publication, New Delhi, 166pp.

Duke, N.C. \& B.R. Jakes (1987). A systematic revision of the mangrove genus Sonneratia (sonneratiaceae) in Australia. Blumea 32: 277-302.

Ellison, A.M. (2000). Mangrove restoration: Do we know enough?. Restoration Ecology 8: 219-229.

Ellison, J. (2005). Holocene palynology and sea-level change in two estuaries in southern Irian Jaya. Palaeogeography, Palaeoclimatology, Palaeoecology 220: 291-309.

Ellison, A.M. \& E.J. Farnsworth (2001). Mangrove community ecology, pp. 423-442. In: Bertness, M.D., S. Gaines \& M.E. Hay (eds.). Marine Community Ecology. Sinauer Press, Sunderland, Massachusetts, 550pp.

Giri, C., Z. Zhu, L.L. Tieszen, A. Singh, S. Gillette \& J.A. Kelmelis (2008). Mangrove forest distribution and dynamics (1975-2005) of the tsunami-affected region of Asia. Journal of Biogeography 35: 519-528.

Haining, Q., S. Graham \& M.G. Gilbert (2007). Flora of
China, Lythraceae. Harvard University Herbaria. Electronic database accessible at http://flora.huh.harvard.edu/china/ PDF/PDF13/Sonneratia.pdf

Mabberley, D.J. (2005). The Plant-book: A Portable Dictionary of The Vascular Plants. Cambridge University press, Cambridge, $858 \mathrm{pp}$.

McKee, K.L. (2005). Global change impacts on mangrove ecosystems. Electronic database accessible at http://www. nwrc.usgs.gov/ factshts/2004-3125.pdf. Geological Survey National Wetlands Research Center, Lafayette, U.S.

Mandal, R.N. \& K.R. Naskar (2008). Diversity and classification of Indian Mangroves: a review. Tropical Ecology 49(2): 131-146.

Nehru, P. \& P. Balasubramanian (2011). Re-colonizing mangrove species in tsunami devastated habitats at Nicobar Islands, India. CheckList 7(3): 253-256.

Polidoro, B.A., K.E. Carpenter, L. Collins, N.C. Duke, A.M. Ellison, J.C. Ellison, E.J. Farnsworth, E.S. Fernando, K. Kathiresan, N.E. Koedam, S.R. Livingstone, T. Miyagi, G.E. Moore, V.N. Nam, J.E. Ong, J.H. Primavera, S.G. Salmo III, J.C. Sanciangco, S. Sukardjo, Y. Wang \& J.W.H. Yong (2010). The Loss of Species: Mangrove Extinction Risk and Geographic Areas of Global Concern. Plos One 5(4): 1-10.

Porwal, M.C., H. Padalia \& P.S. Roy (2012). Impacts of tsunami on the forest and biodiversity richness in Nicobar Islands (Andaman and Nicobar Islands), India. Biodiversity and Conservation 21: 1267-1287.

Ramachandran, S., S. Anitha, V. Balamurugan, K. Dharanirajan, K.E. Vendhan, M.I.P. Divien, A.S. Vel, I.S. Hussain \& A. Udayaraj (2005). Ecological impact of tsunami on Nicobar Islands (Camorta, Katchal, Nancowry and Trinkat). Current Science 89(1): 195-200.

Sankaran, R. (2005). Impact of the earthquake and the tsunami on the Nicobar Islands, pp. 10-77. In: Kaul, R. \& V. Menon (eds.). The Ground Beneath The Waves: Posttsunami Impact Assessment of Wildlife and Their Habitats in India-Vol. 2 - The Islands. Wildlife Trust of India, New Delhi, 103pp.

Sivakumar, K. (2007). Impact of the 2004 tsunami on the Vulnerable Nicobar megapode Megapodius nicobariensis. Oryx 44(1): 71-78.

Sridhar, R., T. Thangaradjou, L. Kannan, A. Ramachandran \& S. Jayakumar (2006). Rapid assessment on the impact of tsunami on mangrove vegetation of the Great Nicobar Island. Journal of the Indian Society of Remote Sensing 34(1): 89-93.

Valiela, I., J.L. Bowen \& J.K. York (2001). Mangrove forests: one of the world's threatened major tropical environments. BioScience 51(10): 807-815.

Yi-Feng, Y., S. Bera, K. Naskar, L. Wen-Bo, L. Cheng-Sen (2011). A comparative study of mangrove floras in China and India. Forestry studies in China 13(3): 173-182. 